EGALITA, Jurnal Kesetaraan dan Keadilan Gender, Pusat Studi Gender (PSG) Universitas Islam Negeri Maulana Malik Ibrahim Malang. Copyright @ 2009. Vol. IV Nomor 2 Tahun 2009 : 168 - 177

\title{
PERAN IBU DALAM KEGIATAN \\ PENDAMPINGAN BELAJAR ANAK \\ Melalui Prinsip Individual Learning-Centered
}

\author{
Ahmad Abtokhi \\ Jurusan Matematika fakultas Saintek UIN Maliki Malang \\ Telepon: 081334196608 \\ Email:ahmad_abtokhi@yahoogroups.com
}

\begin{abstract}
This research describing the role of the mother that very central in assisting children's learning activities through the concept of mentoring that focuses on the uniqueness of each individual. This concept is termed a LearningCentered Individuals who see uniquely child has potential, interests and dynamics of each problem, so that the practical assistance should be focused on managing the potential and uniqueness of each individual dynamics problems to deliver the right learning attitude, without forgetting the reaching academic achievement
\end{abstract}

Penelitian ini menggambarkan peran ibu yang sangat sentral dalam membantu kegiatan belajar anak-anak melalui konsep mentoring yang memfokuskan pada keunikan setiap individu. Konsep ini disebut sebagai Learning-Centered Orang-orang yang melihat potensi anak yang unik, minat dan dinamika dari setiap masalah, sehingga bantuan praktis harus difokuskan pada pengelolaan potensi dan keunikan setiap individu masalah dinamika untuk menyampaikan sikap belajar yang benar, tanpa melupakan pencapaian prestasi akademis 
Keywords: Ibu, pendampingan, belajar, Individual Learning-Centered

\section{Pendahuluan}

Berkembangnya ide feminisme yang begitu pesat beberapa waktu terakhir ini terasa berpengaruh terhadap cara pandang masyarakat terhadap peran ibu. Peran ibu dianggap tidak produktif karena tidak menghasilkan materi. Bahkan beberapa pihak cenderung menganggap peran ibu tersubordinasi oleh peran suami. Padahal, fakta membuktikan bahwa peran ibu khususnya dalam pendidikan anak tidaklah tergantikan. Bahkan Rasulullah SAW memberikan penegasan pada sebuah hadist sebagai berikut,

"Wanita (seorang ibu) itu adalah mengurus di dalam rumah suaminya dan mendidik putra-putrinya" (Al Hadist Syarif)

Pada usia 0 sampai 6 tahun, bagi anak adalah masa keemasan pertumbuhan dan perkembangannya. Pada usia ini, otak anak terbentuk sampai $80 \%$, kecerdasan dan dasar-dasar kepribadiannya mulai terbentuk (Hestiana, 2009). Karena itu, masa ini membutuhkan pendampingan dari sosok yang intens mengikuti pertumbuhan dan perkembangannya, yang mampu memberikan stimulasi optimal dengan penuh kasih sayang. Pembantu atau pengasuh bayi tentu jauh dari kriteria itu. Tempat Pendidikan Anak Usia Dini (PAUD) atau kelompok bermain yang diikuti anak juga sebenarnya tidak dapat memberikan stimulasi optimal. Tempat ini dirancang untuk menangani banyak anak, sehingga kebutuhan individu anak akan kasih sayang tidak terpenuhi seperti bila ibu yang intens mengasuhnya. Kasih sayang adalah salah satu makanan otak, yang membuat otak berkembang optimal selain gizi dan stimulasi. Pengasuhan dengan kasih sayang yang tulus juga dibutuhkan anak dalam perkembangan kecerdasan emosionalnya. Ketika anak merasa disayang, ia belajar untuk menghargai dirinya, menumbuhkan rasa percaya diri, kemampuan untuk berempati dan berbagi kasih sayang kepada orang lain.

Salah satu tugas lanjutan sesuai perkembangan usia anak yang harus dilakukan oleh ibu pada saat anak menginjak usia sekolah adalah mendampingi anak dalam kegiatan belajar, meskipun untuk memberikan pendampingan belajar, tidak ada urusan perseorangan (ibu saja atau ayah saja). Namun bisa dilakukan menurut kedekatan perasaan si anak, lebih nyaman belajar dengan siapa. Kegiatan ini menjadi gampang bila segala sesuatu yang dipersiapkan oleh orang tua terutama ibu sehingga mendapat respon dan hasil yang baik dari anak. Sebaliknya, pendampingan akan mengalami 
hambatan saat respon dan hasil dari si buah hati tidak seperti yang diharapkan. Pada kenyataannya, seringkali hambatan dalam mendampingi anak akan berpengaruh terhadap kualitas dan prestasi belajar mereka. Anak cenderung malas, dan pada akhirnya sikap belajarnya berkurang, bahkan tidak ada sama sekali.

\section{Pendampingan Belajar}

Pendampingan merupakan suatu aktivitas yang dilakukan dan dapat bermakna pembinaan, pengajaran, pengarahan dalam individu atau kelompok yang lebih berkonotasi pada menguasai, mengendalikan, dan mengontrol (BPKB Jawa Timur, 2001).

Belajar merupakan salah satu faktor yang mempengaruhi dan berperan penting dalam pembentukan pribadi dan perilaku individu. Nana Syaodih Sukmadinata (2005) menyebutkan bahwa sebagian besar perkembangan individu berlangsung melalui kegiatan belajar. Berikut adalah pengertian belajar dari para ahli:

- Moh. Surya (1997): "belajar dapat diartikan sebagai suatu proses yang dilakukan oleh individu untuk memperoleh perubahan perilaku baru secara keseluruhan, sebagai hasil dari pengalaman individu itu sendiri dalam berinteraksi dengan lingkungannya".

- Witherington (1952): "belajar merupakan perubahan dalam kepribadian yang dimanifestasikan sebagai pola-pola respons yang baru berbentuk keterampilan, sikap, kebiasaan, pengetahuan dan kecakapan".

- Crow \& Crow dan (1958): "belajar adalah diperolehnya kebiasaankebiasaan, pengetahuan dan sikap baru".

- Hilgard (1962): "belajar adalah proses dimana suatu perilaku muncul perilaku muncul atau berubah karena adanya respons terhadap sesuatu situasi"

- Di Vesta dan Thompson (1970): “ belajar adalah perubahan perilaku yang relatif menetap sebagai hasil dari pengalaman".

- Gage \& Berliner : "belajar adalah suatu proses perubahan perilaku yang yang muncul karena pengalaman"

Dari beberapa pengertian belajar tersebut diatas, kata kunci dari belajar adalah perubahan perilaku. Dalam hal ini, Moh Surya (1997) mengemukakan ciri-ciri dari perubahan perilaku, yaitu:

1. Perubahan yang disadari dan disengaja (intensional).

Perubahan perilaku yang terjadi merupakan usaha sadar dan disengaja dari individu yang bersangkutan. Begitu juga dengan hasil-hasilnya, individu 
yang bersangkutan menyadari bahwa dalam dirinya telah terjadi perubahan, misalnya pengetahuannya semakin bertambah atau keterampilannya semakin meningkat, dibandingkan sebelum dia mengikuti suatu proses belajar.

2. Perubahan yang berkesinambungan (kontinyu).

Bertambahnya pengetahuan atau keterampilan yang dimiliki pada dasarnya merupakan kelanjutan dari pengetahuan dan keterampilan yang telah diperoleh sebelumnya. Begitu juga, pengetahuan, sikap dan keterampilan yang telah diperoleh itu, akan menjadi dasar bagi pengembangan pengetahuan, sikap dan keterampilan berikutnya.

3. Perubahan yang fungsional.

Setiap perubahan perilaku yang terjadi dapat dimanfaatkan untuk kepentingan hidup individu yang bersangkutan, baik untuk kepentingan masa sekarang maupun masa mendatang.

4. Perubahan yang bersifat positif.

Perubahan perilaku yang terjadi bersifat normatif dan menujukkan ke arah kemajuan

5. Perubahan yang bersifat aktif.

Untuk memperoleh perilaku baru, individu yang bersangkutan aktif berupaya melakukan perubahan.

6. Perubahan yang bersifat pemanen.

Perubahan perilaku yang diperoleh dari proses belajar cenderung menetap dan menjadi bagian yang melekat dalam dirinya

7. Perubahan yang bertujuan dan terarah.

Individu melakukan kegiatan belajar pasti ada tujuan yang ingin dicapai, baik tujuan jangka pendek, jangka menengah maupun jangka panjang.

8. Perubahan perilaku secara keseluruhan.

Perubahan perilaku belajar bukan hanya sekedar memperoleh pengetahuan semata, tetapi termasuk memperoleh pula perubahan dalam sikap dan keterampilannya.

Menurut Gagne (Abin Syamsuddin Makmun, 2003), perubahan perilaku yang merupakan hasil belajar dapat berbentuk:

1. Informasi verbal; yaitu penguasaan informasi dalam bentuk verbal, baik secara tertulis maupun tulisan, misalnya pemberian nama-nama terhadap suatu benda, definisi, dan sebagainya.

2. Kecakapan intelektual; yaitu keterampilan individu dalam melakukan interaksi dengan lingkungannya dengan menggunakan simbol-simbol, misalnya: penggunaan simbol matematika.Termasuk dalam keterampilan 
intelektual adalah kecakapan dalam membedakan (discrimination), memahami konsep konkrit, konsep abstrak, aturan dan hukum. Ketrampilan ini sangat dibutuhkan dalam menghadapi pemecahan masalah.

3. Strategi kognitif; kecakapan individu untuk melakukan pengendalian dan pengelolaan keseluruhan aktivitasnya. Dalam konteks proses pembelajaran, strategi kognitif yaitu kemampuan mengendalikan ingatan dan cara-cara berfikir agar terjadi aktivitas yang efektif. Kecakapan intelektual menitikberatkan pada hasil pembelajaran, sedangkan strategi kognitif lebih menekankan pada pada proses pemikiran.

4. Sikap; yaitu hasil pembelajaran yang berupa kecakapan individu untuk memilih macam tindakan yang akan dilakukan. Dengan kata lain. Sikap adalah keadaan dalam diri individu yang akan memberikan kecenderungan bertindak dalam menghadapi suatu obyek atau peristiwa, didalamnya terdapat unsur pemikiran, perasaan yang menyertai pemikiran dan kesiapan untuk bertindak.

5. Kecakapan motorik; ialah hasil belajar yang berupa kecakapan pergerakan yang dikontrol oleh otot dan fisik.

Sementara itu, Moh. Surya (1997) mengemukakan bahwa hasil belajar akan tampak dalam:

1. Kebiasaan; seperti: peserta didik belajar bahasa berkali-kali menghin dari kecenderungan penggunaan kata atau struktur yang keliru, sehingga akhirnya ia terbiasa dengan penggunaan bahasa secara baik dan benar.

2. Keterampilan; seperti: menulis dan berolah raga yang meskipun sifatnya motorik, keterampilan-keterampilan itu memerlukan koordinasi gerak yang teliti dan kesadaran yang tinggi.

3. Pengamatan; yaitu proses menerima, menafsirkan, dan memberi arti rangsangan yang masuk melalui indera-indera secara obyektif sehingga peserta didik mampu mencapai pengertian yang benar.

4. Berfikir asosiatif; yaitu berfikir dengan cara mengasosiasikan sesuatu dengan lainnya dengan menggunakan daya ingat.

5. Berfikir rasional dan kritis yaitu menggunakan prinsip-prinsip dan dasar-dasar pengertian dalam menjawab pertanyaan kritis seperti "bagaimana" (how) dan "mengapa" (why).

6. Sikap yaitu kecenderungan yang relatif menetap untuk bereaksi dengan cara baik atau buruk terhadap orang atau barang tertentu sesuai dengan pengetahuan dan keyakinan.

7. Inhibisi (menghindari hal yang mubazir). 
8. Apresiasi (menghargai karya-karya bermutu).

9. Perilaku afektif yaitu perilaku yang bersangkutan dengan perasaan takut, marah, sedih, gembira, kecewa, senang, benci, was-was dan sebagainya.

Sedangkan menurut Bloom, perubahan perilaku yang terjadi sebagai hasil belajar meliputi perubahan dalam kawasan (domain) kognitif, afektif dan psikomotor, beserta tingkatan aspek-aspeknya. Selain itu, menurut Slavin (2000) belajar adalah perubahan yang relatif permanen dalam perilaku atau potensi perilaku sebagai hasil dari pengalaman atau latihan yang diperkuat.

Belajar merupakan akibat adanya interaksi antara stimulus dan respon. Seseorang dianggap telah belajar sesuatu jika dia dapat menunjukkan perubahan perilakunya. Menurut teori ini dalam belajar yang penting adalah input yang berupa stimulus dan output yang berupa respon. Stimulus adalah apa saja yang diberikan guru kepada pelajar, sedangkan respon berupa reaksi atau tanggapan pelajar terhadap stimulus yang diberikan oleh guru tersebut. Proses yang terjadi antara stimulus dan respon tidak penting untuk diperhatikan karena tidak dapat diamati dan tidak dapat diukur. Yang dapat diamati adalah stimulus dan respon, oleh karena itu apa yang diberikan oleh guru (stimulus) dan apa yang diterima oleh pelajar (respon) harus dapat diamati dan diukur.

Secara praktis, ruang lingkup kegiatan pendampingan belajar berbeda dengan kegiatan pengajaran atau ruang lingkup akademis. Ruang lingkup pengajaran atau ruang lingkup akademis lebih bersifat kolektif (ada interaksi dalam sebuah komunitas), formal (ada peraturan dan tata cara tertentu) dan berfokus pada kemajuan kognitif yaitu kemajuan prestasi belajar dengan memacu kemampuan intelegensi anak.

Sebaliknya, ruang lingkup pendampingan bersifat lebih personal-dialogis (ada kedekatan antara yang mendampingi dan yang didampingi), informal (fleksibel) dan berfokus pada kemajuan psikologis yaitu kemajuan dalam membangun sikap belajar yang baik dan benar tanpa melupakan aspek prestasi akademiknya, sehingga ke depan anak diharapkan tetap survive atau bertahan dalam kehidupan secara umum bukan hanya sekedar kehidupan akademisnya saja.

\section{Prinsip Individual Learning-Centered}

Prinsip Individual Learning-Centered merupakan salah satu pilihan dalam kegiatan pendampingan belajar, prinsip pendampingan ini menekankan 
adanya kedekatan antara pihak yang mendampingi dan yang didampingi, sehingga kegiatan ini akan lebih tepat dan berarti jika dilakukan oleh orang tua, terutama ibu sebagai seseorang yang dalam kesehariannya memiliki kedekatan emosional dengan anak. Anak sebagai seseorang yang didampingi dapat menyampaikan secara dialogis segala permasalahan, baik permasalahan pembelajaran di sekolah maupun permasalahan lain yang berkaitan dengan kehidupan sosialnya, sementara ibu sebagai seseorang yang mendampingi dapat memberikan tawaran solusi, atau meminta kepada pihak lain untuk memecahkannya.

Salah satu prinsip pendampingan ini adalah terletak pada ruang lingkup pendampingan. Walaupun anak tidak dibekali bakat jenius sejak lahir, tetapi pendampingan yang benar akan melahirkan sikap belajar yang benar. Sikap belajar yang benar inilah yang akan menutupi kekurangan anak, memproses mental belajar yang benar dan membuat anak melahirkan prestasi yang sama hebatnya dengan anak-anak yang jenius sejak lahir.

Djamarah (dalam Tarmizi, 2009) berpendapat bahwa sesuatu yang belum diketahui dapat mendorong anak belajar untuk mencari tahu. Anak pun mengambil sikap seiring dengan minatnya terhadap suatu objek. Anak mempunyai keyakinan dan pendirian tentang apa yang seharusnya dilakukannya. Sikap itulah yang mendasari dan mendorong ke arah perbuatan belajar. Jadi, sikap anak dapat dipengaruhi oleh motivasi sehingga ia dapat menentukan sikap belajar.

Selanjutnya menurut Walgito (2004), "Sikap mengandung tiga komponen: kognitif (konseptual), afektif (emosional), konatif (perilaku atau action component)." Komponen kognitif yaitu komponen yang berkaitan dengan pengetahuan, pandangan, keyakinan, yaitu hal-hal yang berkaitan dengan bagaimana orang mempersepsi objek sikap. Komponen afektif yaitu yang berhubungan rasa senang atau tidak senang terhadap objek sikap. Komponen konatif yaitu komponen yang berkaitan dengan kecenderungan untuk berperilaku terhadap objek sikap. Komponen ini menunjukkan intensitas sikap, yaitu menunjukkan besar kecilnya kecenderungan bertindak atau berperilaku seseorang terhadap objek sikap. Di antara ketiga konpomen sikap tersebut dapat dijelaskan bahwa komponen sikap afektif perlu mendapatkan penekanan secara khusus karena sikap afektif ini merupakan sumber motifasi yang terdapat di dalam diri anak. Untuk melihat lebih lanjut mengenai sikap belajar sebenarnya ada sesuatu yang melatarbelakangi mengapa anak mengambil sikap. Hal ini berkaitan erat dengan fungsi sikap (Tarmizi, 2009), sebagai berikut: 
1) Sikap sebagai instrumen atau alat untuk mencapai tujuan (instrumental function).

Seseorang mengambil sikap tertentu terhadap objek atas dasar pemikiran sampai sejauh mana objek sikap tersebut dapat digunakan sebagai alat atau instrumen untuk mencapai tujuan yang ingin dicapai. Kalau objek itu mendukung dalam penca-paian tujuan, maka orang akan mempunyai sikap yang positif terhadap objek yang bersangkutan, demikian pula sebaliknya. Fungsi ini juga sering disebut sebagai fungsi penyesuaian (adjustment), karena dengan mengambil sikap tertentu seseorang akan dapat menyesuaikan diri dengan keadaan lingkungannya.

2) Sikap sebagai pertahanan ego

Kadang-kadang orang mengambil sikap tertentu terhadap sesuatu objek karena untuk mempertahankan ego atau akunya. Apabila seseorang merasa egonya terancam maka ia akan mengambil sikap tertentu terhadap objek demi pertahanan egonya. Misalnya orang tua mengambil sikap begitu keras (walaupun sikap itu sebetulnya tidak benar), hal tersebut mungkin karena dengan sikap keadaan ego atau aku-nya dapat dipertahankan.

3) Sikap sebagai ekspresi nilai

Sikap yang diambil oleh seseorang yang mencerminkan sistem nilai yang ada pada diri orang tersebut.

4) Sikap sebagai fungsi pengetahuan

Ini berarti bahwa bagaimana sikap seseorang terhadap sesuatu objek akan mencerminkan keadaan pengetahuan dari orang tersebut. Apabila pengetahuan seseorang mengenai sesuatu belum konsisten maka hal itu akan berpengaruh pada sikap orang itu terhadap objek tersebut.

Anak mempunyai sikap positif terhadap suatu objek yang bernilai dalam pandangannya, dan ia akan bersikap negatif terhadap objek yang dianggapnya tidak bernilai dan atau juga merugikan. Sikap ini kemudian mendasari dan mendorong ke arah sejumlah perbuatan yang satu sama lainnya saling berhubungan.

Secara praktis, berikut beberapa metode yang tepat digunakan dalam proses pendampingan belajar melalui prinsip Individual Learning-Centered:

1. Berbagi Informasi (Information Sharing) melalui curah pendapat maupun diskusi bersama antara ibu dan anak dengan cara membahas permasalahan bersama, dengan mengemukakan dasar alasan untuk mencari solusi. Kegiatan ini berguna untuk merangsang keberanian dan kreativitas anak dalam mengemukakan gagasan, menggali ide bahkan ide baru 
yang dimiliki oleh anak yang mungkin selama ini belum terungkap, bahkan melatih anak untuk dapat menghargai pendapat orang lain. Berlatih membiasakan diri berargumentasi dan berfikir rasional, juga membiasakan diri untuk meyakinkan orang lain, dan belajar bertanggung jawab terhadap hasil pemikiran.

2. Belajar dari Pengalaman (Experience Based) dengan cara simulasi, bermain peran, dan permainan yang bertujuan memberikan pengalaman yang lebih nyata kepada anak sehingga dia dapat merasakan apa yang terjadi pada setiap permasalahan. Dengan metode ini diharapkan anak akan lebih memahami sekaligus belajar dari berbuat atau meniru sehingga pada akhirnya pendampingan belajar lebih bermakna karena melibatkan interaksi anak dengan kondisi riil, kemampuan kerjasama, komunikatif. Selain itu anak diharapkan mampu mencoba mengeksplorasi hubungan-hubungan antarma-nusia dengan cara mengeksplorasi perasaan-perasaan, sikapsikap, nilai-nilai, dan berbagai strategi pemecahan masalah.

3. Pembelajaran melalui Pemecahan Masalah (Problem Solving Based) dengan cara studi kasus yang bertujuan dapat mengembangkan pengetahuan, sikap, pemecahan masalah, keterampilan mengunakan pengetahuan secara bermakna, kemampuan komunikasi berfikir kritis, dan menemukan solusi baru terhadap permasalah yang dihadapi anak. pemahaman, keterampilan. Sedangkan dampak yang mengiringnya adalah hakikat tentatif keilmuan, keterampilan proses keilmuan, otonomi dan kebebasan anak, toleransi terhadap ketidakpastian dan masalah-masalah non rutin.

\section{Kesimpulan}

Peran ibu dalam kegiatan pendampingan belajar memiliki peran yang sentral. Hal tersebut disebabkan selain ibu sebagai seseorang yang dalam kesehariannya memiliki kedekatan emosional dengan anak, pendampingan juga merupakan salah satu pondasi vital bagi kemajuan anak secara umum, bukan hanya pada segi akademik saja, lebih dari itu aspek afektif, dan konatif dapat diapresiasikan oleh seorang ibu kepada anak pada saat pendampingan. Secara konseptual, salah satu konsep pendampingan belajar anak adalah pendampingan yang terfokus pada keunikan setiap individu. Artinya setiap anak dipandang secara unik memiliki potensi, minat dan dinamika masalahnya masing-masing, sehingga konsep Individual Learning-Centered yang bukan sekedar dimaknai sebagai pendampingan yang bersifat individualis, tetapi sebagai pendampingan yang bersifat personaldialogis serta terfokus untuk mengelola keunikan potensi dan dinamika per- 
masalahan setiap individu untuk melahirkan sikap belajar yang benar tanpa melupakan pencapaian prestasi akademiknya.

\section{DAFTAR PUSTAKA}

Abin Syamsudin Makmun. 2003. Psikologi Pendidikan. Bandung: PT. Rosda Remaja Karya.

BPKB Jawa Timur, 2001. Modul Pendampingan, Surabaya.

Hestiana. 2009. Happy Mother Day. Desember 2009 (diakses 23 Desember 2009).

http://tarmizi.wordpress.com/2009/03/08/komponen pembentukan sikap belajar anak/ (diakses 20 Desember 2009).

Purwati, Sri. 2006. Bentuk Pendampingan Belajar dalam Keluarga bagi Anak Berprestasi Kelas IV Tahun Pelajaran 2004 - 2005 SD Strada Bhakti Utama Jakarta Selatan. Thesis. Unika Atma Jaya. Jakarta.

Sukmadinata, Nana Syaodih. 2005. Landasan psikologi proses pendidikan Bibliografi. Bandung: Remaja Rosdakarya.

Slavin. 1994. Educational Psychology, Theory and Practice. Needham Heights: Allyn \& Bacon.

Walgito, Bimo. 2004. Bimbingan \& Konseling di Sekolah. Yogyakarta: Andi Offset.

Wanei, Gerda K. 2008. Meningkatkan Sikap Belajar Positif Terhadap Pelaksanaan Tata Tertib Sekolah Melalui Pemberian Motivasi dan Penguatan Anak Kelas 1 SD. Thesis. Jakarta: Unika Atma Jaya. 